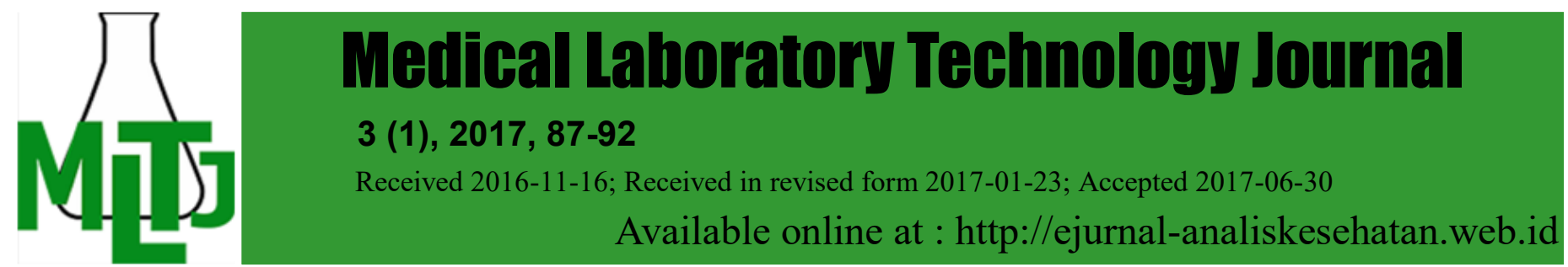

\title{
CEMARAN BAKTERI GRAM NEGATIF PADA JAJANAN SIOMAY DI KOTA KENDARI
}

\author{
Reni Yunus, Ruth Mongan, Rosnani \\ Jurusan Analis Kesehatan Poltekkes Kemenkes Kendari \\ JI. Jend. A.H. Nasution. No. G.14 Anduonohu, Kota Kendari \\ e-mail: reni_yunus@yahoo.co.id
}

\begin{abstract}
Foodborne disease caused by food infection is one of health concern which cause of consumption of contaminated foods that containing living microorganisms. There are several kinds of microorganisms that can cause food infection, one of them is Salmonella sp, a negative Gram basil shaped-bacteria as the cause typhoid and paratyphoid diseases. The purpose of this study is isolate and identify negative Gram bacteria on snacks in the traditional market Anduonuhu Kendari. This research is a descriptive study with dumplings samples which sale on the traditional Market Anduonohu as population. Samples were taken as a total sampling with pour plate method was used for bacterial isolation. All 10 samples were shown positive result which growth in Brain Heart Infusion Broth media as 7 of them are positively grow in Salmonella Shigella Agar with negative Gram basil-shaped bacteria was found under the microscope after Gram staining, suspected as negative Gram baceria. It can be concluded that 7 $(70 \%)$ out of of 10 dumplings samples were contaminated negative Gram bacteria. This research can be continued by identifying other pathogenic bacteria which are the bacteria that cause food borne disease.
\end{abstract}

Keywords: Gram-negative bacteria ; Siomay

Abstrak: Penyakit bawaan makanan disebabkan oleh infeksi makanan adalah salah satu masalah kesehatan akibat konsumsi makanan yang terkontaminasi mengandung mikroorganisme. Ada beberapa jenis mikroorganisme yang dapat menyebabkan infeksi makanan, salah satunya adalah Salmonella sp, bakteri berbentuk batang Gram negatif yang dapat menyebabkan tipus dan penyakit paratifoid. Tujuan dari penelitian ini adalah untuk mengisolasi dan mengidentifikasi bakteri Gram negatif pada jajanan siomay yang dijual di pasar tradisional Anduonuhu Kendari. Penelitian ini merupakan penelitian deskriptif dengan sampel sioamay yang dijual di Pasar tradisional Anduonohu tradisional. Sampel penelitian diambil secara total sampling dengan metode pour plate digunakan untuk isolasi bakteri. Keseluruhan 10 sampel menunjukkan pertumbuhan yang positif di media Brain Hearth Infusion Broth, dan terdapat 7 yang positif tumbuh pada media Salmonella shigella agar yang merupakan bakteri Gram negatif berbentuk batang dari pengamatan di bawah mikroskop setelah pewarnaan Gram. Dapat disimpulkan bahwa 7 (70\%) dari 10 sampel siomay terkontaminasi dengan bakteri Gram negatif. Penelitian ini dapat dilanjutkan dengan melakukan identifikasi bakteri lain yang patogen yang merupakan bakteri penyebab food borne disease.

Kata kunci: bakteri Gram negatif; siomay 


\section{PENDAHULUAN}

Penyakit bawaan makanan (Foodborne disease) adalah penyakit yang di timbulkan oleh makanan yang terkontaminasi (Arlita Y, 2013).Volk dan Wheller (1993) menyatakan bahwa foodborne disease yang disebabkan oleh bakteri dapat dibagi menjadi dua kelompok besar, yaitu infeksi makanan dan keracunan makanan. Indonesia merupakan negara berkembang dengan angka kejadian penyakit infeksi yang tinggi yang didominasi oleh infeksi saluran nafas dan infeksi saluran cerna, kemudian infeksi lainnya seperti infeksi saluran kemih, kulit, bahkaninfeksi sistemik. Salah satu faktor yang meningkatkan kemungkinan terjadinya infeksi adalah kecenderungan untuk tidak menjaga kebersihan, terutama dalam masalah makanan dan minuman (Wijaya,2011).

Makanan dan minuman dapat terkontaminasi oleh berbagai macam mikroorganisme yang dapat mencemari makanan, diantaranya adalah Salmonella sp. Bakteri ini merupakan agen penyebab salmonellosis. Pada beberapa tahun terakhir ini, peranan Salmonella sp sebagai agen penyebab Food Borne Disease menjadi perhatian dunia, karena peningkatan kejadian salmonellosis baik pada hewan maupun manusia (Narumi E, 2009).

Resiko penularan mikroorganisme dapat terjadi, apabila pengolahan makanan yang tidak bersih, hal ini dapat menjadi awal mula terdapatnya mikroba pada makanan. Berdasarkan UU Makanan No. 7 tahun 1996, keamanan makanan adalah kondisi dan upaya yang diperlukan untuk mencegah makanan dari kemungkinan cemaran biologis, kimia dan benda lain yang dapat mengganggu, merugikan dan membahayakan kesehatan manusia. Bakteri dalam makanan/ minuman diakibatkan oleh penjualan makanan yang tidak memperhatikan kebersihan dan keamanannya (Arlita Y, dkk, 2013).

Dari data Kejadian Luar Biasa (KLB) keracunan pangan oleh BPOM tahun 2011 menunjukkan bahwa telah terjadi $128 \mathrm{KLB}$ keracunan pangan dilndonesia, 38 kasus $(29,69 \%)$ KLB keracunan pangan tersebut diakibatkan oleh cemaran mikroba, 19 kasus $(14,84 \%)$ akibat keracunan cemaran kimia, dan 71 kasus $(55,47 \%)$ tidak diketahui penyebabnya (Putriana,dkk, 2012). Lebih lanjut telah dilaporkan bahwa pada tahun 2000, kasus infeksi Salmonella sp berjumlah 1.487 orang pada usia dewasa dan 3.310 orang pada semua usia. Di kota Kendari sendiri kasus penyakit tifus pada tahun 2013 dilaporkan sebanyak 664 kasus (Profil Dinkes Kota Kendari, 2013).

Jajanan siomay merupakan salah satu makanan yang banyak diminati oleh masyarakat dan dijual bebas di pasar tradisional. Makanan ini rentan terkontaminasi oleh berbagai bakteri penyebab food borne disease karena makanan ini dijual bebas tanpa memperhatikan lingkungan tempat penjualannya. Kurangnya hygiene sanitasi jajanan siomay yang dijual di Pasar Andonuhu memungkinkan adanya kontaminasi bakteri Salmonella sp (Adin S, 2015).

Analisis mikrobiologi penting dalam menentukan keamanan dan kualitas dari suatu makanan, oleh sebab itu pada penelitian ini dimaksudkan untuk mengindentifikasi bakteri Gram negatif pada jajanan siomay yang dijual di Pasar Anduonuhu Kecamatan Poasia Kota Kendari.

\section{BAHAN DAN METODE}

Penelitian ini bersifat deskriptif yaitu untuk mengidentifikasi bakteri Gram negatif pada jajanan siomay yang dijual di Pasar Anduonuhu Kecamatan Poasia Kota Kendari, dengan melakukan pengujian di Laboratorium.

Tempat pengambilan sampel di Pasar Andounuhu Kecamatan Poasia Kota Kendari Provinsi, dan tempat pemeriksaan sampel dilakukan di Laboratorium Analis Kesehatan Poltekkes Kendari. Populasi dalam penelitian ini adalah seluruh jajanan siomay yang dijual di Pasar Anduonuhu Kecamatan Poasia Kota Kendari Provinsi Sulawesi Tenggara. Sampel dalam penelitian ini adalah jajanan siomay yang dijual di pasar Anduonuhu sebanyak 50 Gram siomay yang diambil dari 10 penjual siomay. Teknik pengambilan sampel dalam penelitian yaitu dengan menggunakan total sampling.

Alat penelitian ini adalah autoclave, erlenmeyer, gelas kimia, gelas ukur, rak tabung, tabung reksi, Sendok tanduk, batang pengaduk, lampu spiritus, pipet ukur dan karet, Mikroskop, karet pengisap, ose, timbangan analitik, lampu spiritus, pipet tetes, objek glass. Bahan yang digunakan dalam penelitian ini adalah media Brain Heart Infusion Broth (BHIB), media Salmonella Shigella Agar (SSA), Indikator $\mathrm{pH}$,aquadest, kapas, NaCL 0,96\%, kertas label, Gentian violet, Lugol $3 \%$, Alkohol $96 \%$, air fuchsin, oil imersi. 
Prosedur Pemeriksaan Laboratorium

Alat-alat yang digunakan terlebih dahulu disterilkan dalam autoclave untuk membebaskan tiap benda atau substansi dari semua kehidupan dalam bentuk apapun. Sebelum sterilisasi terlebih dahulu diperiksa air pada autoklaf kemudian dimasukan alat dan bahan yang sudah dibungkus rapi dengan kertas kemudian tutup autoklaf skrup pengaman. Sterilisasi dilakukan selama 15 menit pada suhu $121^{\circ} \mathrm{C}$, tekanan $1 \mathrm{~atm}$.

Pembuatan Media Brain Heart Infusion Broth (BHIB) merk Oxoid dengan cara media BHIB sebanyak 4,44 Gram dimasukkan kedalam erlenmeyer $250 \mathrm{~mL}$ dan dilarutkandengan aquadest sebanyak 120 $\mathrm{mL}$, buat sesuai kebutuhan dan ukur $\mathrm{pH}$ dengan indicator $\mathrm{pH} 7,4 \pm 0,2$. Selanjutnya dipanaskan sampai larut dengan baik, setelah itu, disterilisasi dengan autoclave pada suhu $121^{\circ} \mathrm{C}$ selama 15 menit.

Pembuatan MediaSalmonella Shigella Agar (SSA) merk oxoid dengan cara media Salmonella Shigella Agar(SSA) 10,2 Gram diimasukkan kedalam erlenmeyer $250 \mathrm{~mL}$ dan dilarutkan dengan aquadest sebanyak 170 $\mathrm{mL}$, kemudian diukur $\mathrm{pH}$ dengan indikator $\mathrm{pH}$ $7,4 \pm 0,2$.Kemudian dipanaskan sampai larut dengan baik, setelah itu, dibiarkan hingga dingin kemudian dipanaskan kembali lalu dituang kedalam cawan petri, biarkan hingga padat.

Inokulasi sampel siomay Pada Media Brain Heart Infusion Broth (BHIB) dilakukan dengan cara sampel siomay dengan bumbu kacang ditimbang sebanyak 5 Gram kemudian dihaluskan dan ditambahkan dengan aquadest sebanyak $45 \mathrm{~mL}$ aquadest, lalu di homogenkan dan di isolasi pada media Brain Heart Infusion Broth (BHIB) dengan perbandingan 9:1 dimana $9 \mathrm{ml}$ untuk media Brain Heart Infusion Broth (BHIB) dan $1 \mathrm{ml}$ untuk sampel. Selanjutnya diinkubasi media Brain Heart Infusion Broth (BHIB) tersebut selama $1 \times 24$ jam pada suhu $37^{\circ} \mathrm{C}$ di inkubator.Jika terjadi kekeruhan pada Media Brain Heart Infusion Broth (BHIB), dilanjutkan pada media selektif yaitu media SSA.Jika tidak terjadi kekeruhan pada media Brain Heart Infusion Broth (BHIB), tidak di lanjutkan Pada Media Salmonella Shigella Agar (SSA).

Inokulasi Bakteri Pada Media Salmonella Shigella Agar (SSA) dilakukan dengan cara bakteri tersangka pada media Brain Heart Infusion Broth (BHIB), diambil dengan menggunakan ose yang sudah di fiksasi.Diinukolasikan pada media Salmonella Shigella Agar (SSA) dengan cara
digoreskan.Media Salmonella Shigella Agar (SSA) tersebut selanjutnya diinkubasi selama $1 \times 24$ jam pada suhu $37^{\circ} \mathrm{C}$ di incubator. Kemudian diamati ciri koloni yang tumbuh pada Media Salmonella Shigella Agar (SSA) kemudian lakukan pewarnaan Gram.Jika tidak ada pertumbuhan koloni pada Media Salmonella Shigella Agar (SSA) maka tidak dilakukan pada pewarnaan Gram.

Pewarnaan Gram dilakukan dengan cara diteteskan 1 tetes $\mathrm{Nacl} 0,96 \%$ di atas objek glass kemudian diratakan dengan ose.Kemudian biarkan hingga kering lalu fiksasi di atas nyala api kecil.Kemudian diletakan preparat pada jembatan pewarnaan, lalu lakukan pewarnaan Gram. Selanjutnya preparatditetesi dengan larutan gentian violet selama 1 -2 menit kemudian bilas dengan air mengalir.Selanjutnya, ditetesi dengan larutan lugol selama 1 menit. Kemudian bilas dengan air mengalir.Kemudian ditetesi dengan larutan alkohol 96\% selama 30 detik dan bilas dengan air mengalir. Kemudian ditetesi dengan larutan air fuchsin selama 20 detik dan bilas dengan air. Selanjutnya dibiarkan kering, lalu diamati di bawa mikroskop dengan perbesaran 100x dengan menggunakan minyakemersi.

Interprestasi Hasil pada Media Brain Heart Infusion Broth (BHIB) yaitu Positif (+): terjadi kekeruhan pada Media Brain Heart Infusion Broth (BHIB). Negatif (-) : tidak terjadi kekeruhan pada Media Brain Heart Infusion Broth (BHIB)

Interpretasi hasil pada media SSA yaitu Positif (+) Ada pertumbuhan koloni dengan ciri koloni kecil, smooth, tak berwarna (bening) dengan inti hitam, permukaan cembung dengan tepian halus (Brooks dkk, 2005). Negatif (-) Tidak ada pertumbuhan koloni dengan ciri koloni kecil, smooth, tak berwarna (bening) dengan inti hitam, permukaan cembung dengan tepian halus (Brooks dkk, 2005).

Interprestasi hasil pada pewarnaan Gram yaitu Positif (+) ditemukan bakteri Gram negatif berbentuk batang berwarna merah. Negatif (-) tidak ditemukan bakteri Gram negatif berbentuk batang berwarna merah.

\section{HASIL DAN PEMBAHASAN}

terdapat 10 sampel yang mengalami kekeruhan pada media Brain Heart Infusion Broth (BHIB). Hasil kultur pada media Brain Heart Infusion Broth semua menunjukan terjadi kekeruhan yang berarti ada bakteri yang hidup dimedia tersebut. 
Tabel. 1 Hasil pemeriksaan sampel siomay yang diperoleh dari Pasar Anduonohupada media Brain Heart Infusion Broth (BHIB)

\begin{tabular}{|c|c|c|c|}
\hline \multirow[t]{2}{*}{ No } & \multirow[t]{2}{*}{$\begin{array}{c}\text { Kode } \\
\text { sampel }\end{array}$} & \multicolumn{2}{|c|}{$\begin{array}{l}\text { Hasil pertumbuhan } \\
\text { pada media BHIB }\end{array}$} \\
\hline & & Keruh & $\begin{array}{l}\text { Tidak } \\
\text { keruh }\end{array}$ \\
\hline 1 & S.1 & $\sqrt{ }$ & - \\
\hline 2 & S.2 & $\sqrt{ }$ & - \\
\hline 3 & S. 3 & $\sqrt{ }$ & - \\
\hline 4 & S.4 & $\sqrt{ }$ & - \\
\hline 5 & $\mathrm{~S} .5$ & $\sqrt{ }$ & - \\
\hline 6 & S.6 & $\sqrt{ }$ & - \\
\hline 7 & S.7 & $\sqrt{ }$ & - \\
\hline 8 & S.8 & $\sqrt{ }$ & - \\
\hline 9 & S.9 & $\sqrt{ }$ & - \\
\hline 10 & S.10 & $\sqrt{ }$ & - \\
\hline \multicolumn{2}{|c|}{ Jumlah } & 10 & 0 \\
\hline
\end{tabular}

Pada sampel penelitian yang berjumlah 10 sampel menunjukan semua sampel positif (+) keruh yang berarti sampel tersebut ditumbuhi bakteri. Pengujian ini diawali dengan inokulasi sampel pada media Brain Heart Infusion Broth (BHIB) kemudian media diinkubasi selama 24 jam pada suhu $37^{\circ} \mathrm{C}$, hasil pada media Brain Heart Infusion Broth (BHIB ) terjadi perubahan warna dari kuning jernih menjadi keruh yang teramati secara visual, hal ini menandakan bahwa terjadi pertumbuhan bakteri pada media Brain Heart Infusion Broth (BHIB), dimana media BHIB berfungsi sebagai media penyubur yang mempunyai $\mathrm{pH}$ 7,4 dan mengandung sumber nutrisi.Berdasarkan hasil diatas dapat dikatakan bahwa semua sampel telah tercemar mikroorganisme, kemudian dilanjutkan pada media selektif Salmonella Shigella Agar (SSA) dengan cara digores.

Tabel 2. Pengamatan hasil inokulasi pada media Salmonella Shigella Agar (SSA) dengan melihat pertumbuhan koloni.

\begin{tabular}{|c|c|c|c|}
\hline \multirow[t]{2}{*}{ No } & \multirow{2}{*}{$\begin{array}{l}\text { Kode } \\
\text { sampel }\end{array}$} & \multicolumn{2}{|c|}{$\begin{array}{l}\text { Hasil pertumbuhan } \\
\text { pada media SSA }\end{array}$} \\
\hline & & $\begin{array}{c}\text { Positif } \\
(+)\end{array}$ & $\begin{array}{l}\text { Negatif } \\
(-)\end{array}$ \\
\hline 1 & S.1 & $\sqrt{ }$ & - \\
\hline 2 & S.2 & - & $\sqrt{ }$ \\
\hline 3 & S.3 & $\sqrt{ }$ & - \\
\hline 4 & S.4 & $\sqrt{ }$ & - \\
\hline 5 & S.5 & $\sqrt{ }$ & . \\
\hline 6 & S.6 & - & $\sqrt{ }$ \\
\hline 7 & S.7 & $\sqrt{ }$ & - \\
\hline 8 & S. 8 & - & $\sqrt{ }$ \\
\hline 9 & S.9 & $\sqrt{ }$ & - \\
\hline 10 & S.10 & $\sqrt{ }$ & - \\
\hline & imlah & 7 & 3 \\
\hline Pre & sentase & $70 \%$ & $30 \%$ \\
\hline
\end{tabular}

Pada media selektif Salmonella Shigella Agar (SSA), terdapat 7 sampel yang menunjukkan pertumbuhan koloni bakteri dengan bentuk koloni ciri koloni kecil, smooth, tak berwarna (bening) dengan inti hitam, permukaan cembung dengan tepian halus yang diduga sebagai koloni bakteri Salmonella sp, dan 3 sampel tidak ditumbuhi koloni (Brooks dkk, 2005). Tujuh koloni yang tumbuh pada media Salmonella Shigella Agar (SSA) diperiksa lebih lanjut dengan pewarnaan Gram.

Tabel.3 Hasil pewarnaan Gram dari 7 isolat bakteri yang positif tumbuh pada media SSA

\begin{tabular}{|c|c|c|c|c|}
\hline \multirow[t]{2}{*}{ No } & \multirow[t]{2}{*}{$\begin{array}{l}\text { Kode } \\
\text { sampel }\end{array}$} & \multicolumn{2}{|c|}{$\begin{array}{l}\text { Hasil pengamatan } \\
\text { mikroskop pada } \\
\text { pewarnaan gram }\end{array}$} & \multirow[t]{2}{*}{$\begin{array}{c}\text { Hasil } \\
\text { identifikasi }\end{array}$} \\
\hline & & $\begin{array}{c}\text { Batang } \\
\text { gram } \\
\text { negatif }\end{array}$ & $\begin{array}{l}\text { Bukan } \\
\text { batang } \\
\text { gram } \\
\text { negatif }\end{array}$ & \\
\hline 1 & S.1 & $\sqrt{ }$ &. & $\begin{array}{c}\text { Bakteri gram } \\
\text { negatif }\end{array}$ \\
\hline 2 & S.3 & $\sqrt{ }$ & - & $\begin{array}{c}\text { Bakteri gram } \\
\text { negatif }\end{array}$ \\
\hline 3 & S.4 & $\sqrt{ }$ & - & $\begin{array}{c}\text { Bakteri gram } \\
\text { negatif }\end{array}$ \\
\hline 4 & S.5 & $\sqrt{ }$ & - & $\begin{array}{c}\text { Bakteri gram } \\
\text { negatif }\end{array}$ \\
\hline 5 & S.7 & $\sqrt{ }$ & - & $\begin{array}{c}\text { Bakteri gram } \\
\text { negatif }\end{array}$ \\
\hline 6 & S.9 & $\sqrt{ }$ & - & $\begin{array}{c}\text { Bakteri gram } \\
\text { negatif }\end{array}$ \\
\hline 7 & S.10 & $\sqrt{ }$ & - & $\begin{array}{c}\text { Bakteri gram } \\
\text { negatif }\end{array}$ \\
\hline
\end{tabular}


Tabel 3 menunjukan bahwa sampel S.1, sampel S.3, sampel S.4, sampel S.5, sampel S.7, sampel S.9, dan sampel S.10 memperlihatkan morfologi bakteri batang Gram negatif . Hasil identifikasi tersebut menunjukkan bahwa ke 7 isolat tersebut adalah bakteri Gram negatif. Hal ini berarti bahwa frekuensi cemaran bakteri Gram negatif sebanyak $70 \%$ diperoleh hasil positif dan $30 \%$ negatif

Pertumbuhan bakteri pada media SSA dengan ciri koloni yang kecil, smooth, tak berwarna (bening) dengan inti hitam, permukaan cembung dengan tepian halus diduga sebagai koloni bakteri Salmonella sp. Menurut Edi (2012) pertumbuhan Salmonella pada media SSA memperlihatkan pertumbuhan koloni yang tak berwarna (Edi,2012).

Media SSA merupakan media selektif untuk bakteri Salmonella sp, sehingga pertumbuhan bakteri lain yang non salmonelle dapat dihambat. Selanjutnya dilakukan pengamatan mikroskop pada pewarnaan Gram untuk mengetahui bentuk atau morfologi dari bakteri Salmonella sp. Pengamatan yang dilakukan pada penelitian diperoleh hasil positif (+) bentuk morfologi batang berwarna merah pada 7 sampel dari jumlah sampel adalah 10 sampel penelitian. Berdasarkan dari hasil penelitian secara bakteriologis pada 10 sampel jajanan siomay diperoleh hasil positif bakteri Gram negatif berjumlah 7 sampel.

Pertumbuhan bakteri pada media SSA dengan ciri koloni yang kecil, smooth, tak berwarna (bening) dengan inti hitam, permukaan cembung dengan tepian halus diduga sebagai koloni bakteri Salmonella sp. Media SSA merupakan media selektif untuk bakteri Salmonella $s p$, sehingga pertumbuhan bakteri lain yang non salmonelle dapat dihambat. Selanjutnya dilakukan pengamatan mikroskop pada pewarnaan Gram untuk mengetahui bentuk atau morfologi dari bakteri Salmonella sp. Pengamatan yang dilakukan pada penelitian diperoleh hasil positif bentuk morfologi batang berwarna merah pada 7 sampel dari jumlah sampel adalah 10 sampel penelitian. Berdasarkan hasil penelitian, pada 10 sampel jajanan siomay diperoleh hasil positif tersangka bakteri Salmonella berjumlah 7 sampel. Koloni Salmonella $s p$ berwarna hitam karena mampu menghasilkan H2S. Namun demikian, bakteri Salmonella bukan satu-satunya bakteri yang memperlihatkan koloni berwarna hitam.
Selain Salmonella $s p$, Kelompok bakteri Proteus $s p$ dan Enterobacter $s p$ juga memperlihatkan koloni yang sama pada media SSA.

Dengan ditemukannya bakteri Gram negatif yang tersangka Salmonella $s p$ pada siomay tersebut, menunjukkan bahwa lingkungan disekitar tempat penjualan siomay kurang hygienis. Berdasarkan hasil observasi diketahui bahwa lingkungan tempat berjualan dekat lods ikan, ayam dan tempat sampah, makanan dijajakan tidak berpenutup dan pedagang tidak mencuci tangan terlebih dahulu sebelum menyiapkan makanan, sehingga dapat menyebabkan kontaminasi salmonella sp pada makanan. Hal lain yang dapat menyebabkan terjadinya kontaminasi bakteri adalah wadah penyimpanan siomay dan bumbu kacang siomay dalam keadaan terbuka ketika siomay sedang dijajakan kepada pembeli.

Menurut Wahab (2011) Peranan lingkungan serta proses pengolahan sampai penjualan sangat erat kaitanya dengan jumlah dan jenis bakteri yang ditemukan pada siomay. Makanan dan minumanyang terkontaminasi bakteri Salmonella $s p$ dalam jumlah kecil, tidak terlalu menimbulkan perubahan dalam hal warna, bau maupun rasa dari makanan yang tercemar Salmonella spkecuali jika bahan makanan mengandung Salmonella $s p$ dalam jumlah besar maka akan terjadi perubahan warna dan bau. Semakin tinggi jumlah bakteri salmonella $s p$ di dalam suatu makanan, maka semakin besar timbulnya gejalah infeksi pada orang yang menelan makanan tersebut.Infeksi, yaitu suatu penyakit yang disebabkan oleh mikroba yang hidup dan berkembang biak pada tempat tterjadinya peradangan. Mikroba masuk kedalam saluran pencernaan manusia melalui makanan dan minuman, yang kemudian dicerna dan diserap oleh tubuh. Dalam kondisi yang sesuai, mikroba patogen akan berkembang biak didalam saluran pencernaan sehingga menyebabkan gejala penyakit (Yuswananda, 2010).

Bakteri yang terdapat dalam makanan, salah satunya adalah bakteri Salmonella sp. Bakteri Salmonella sp adalah kuman batang bergerak, Gram negatif, fakultatif aerob karena habitat aslinya berada didalam usus manusia maupun hewan. Salmonella $s p$ memiliki ukuran $1-3,5 \mu \mathrm{m} \times 0,5-0,8$, berbentuk batang, tidak berspora dan sebagian besar isolat bersifat motil dengan flagel peritriks (peritrichous flagella). 
Salmonella sp umumnya menghasilkan $\mathrm{H}_{2} \mathrm{~S}$. Organisme ini dapat bertahan pada air yang beku dalam waktu yang lama. Bakteri ini resisten terhadap bahan kimia tertentu (brilliant green, sodium tetrathionat dan sodium deoxycholate) yang menghambat pertumbuhan bakteri enterik lain. Bakteri Salmonella tumbuh pada suhu $15^{\circ} \mathrm{C}-41^{\circ} \mathrm{C}$ (suhu optimum $37,5^{\circ} \mathrm{C}$ dengan $\mathrm{pH}$ 6-8). Perkembangan bakteri Salmonella spterbilang sangat cepat dan menakjubkan, setiap selnya mampu membelah diri setiap 20 menit sekali pada suhu hangat dan pada media tumbuh yang mengandung protein tinggi. satu sel bakteri bisa berkembang menjadi 90.000 hanya dalam waktu 6 jam (Brooks, dkk. 2010).

Salmonella spdapat menimbulkan penyakit pada tubuh manusia yang disebut dengan salmonellossis.Salmonellosis di akibatkan oleh makanan yang tercemar oleh Salmonella spdikonsumsi oleh manusia. Salmonellosis ditandai dengan gejala demam yang timbul secara akut, nyeri abdominal, diare, dan terkadang muntah. Secara klinis Salmonella spdi bedakan menjadi dua macam yaitu Salmonella tifoid yang menyebabkan demam enterik atau demam tifoid dan Salmonella non tifoid yang menyebabkan gastro enteritis (Yuswananda, 2010: 27).

Penelitian ini sejalan dengan penelitian Arlita, dkk (2013) yang dilakukan di Manado yang menunjukan adanya bakteri Salmonella $s p$ pada jajanan bakso tusuk yang dijual di Manado. Begitu pula penelitian yang dilakukan oleh Yuswananda (2015) di Jakarta pada makanan jajanan di Masjid fathulla ciputat yang menunjukan adanya bakteri Salmonella sp pada makanan jajanan.

\section{KESIMPULAN}

Berdasarkan hasil penelitian cemaran bakteri pada jajanan siomay didapatkan hasil 7 sampel siomay sudah tercemar bakteri Gram negatif yang tersangka sebagai bakteri Salmonella sp. dari 10 sampel yang diperiksa, yang ditandai dangan adanya kekeruhan pada media BHIB, adanya pertumbuhan pada media SSA, dan pewarnaan bakteri yang menunjukkan bahwa 7 sampel siomay yang diperiksa merupakan bakteri Gram negatif.

\section{SARAN}

Penelitian ini dapat dilanjutkan dengan melakukan identifikasi bakteri lain yang patogen yang merupakan bakteri penyebab food borne disease.

\section{DAFTAR PUSTAKA}

Adin, S. (2015). Membuat Siomay Bandung Sederhana dan Lezat. Resep makanan.

Alam, C. (2012). Identifikasi Bakteri Pada Ikan Asin Yang Beredar Dipasar Baruga. Akademi Analis Kesehatan Binahusada Kendari.

Arlita, Y. (2013). Identifikasi Bakteri E.coli dan Salmonella sp pada Makanan Jajanan Bakso Tusuk dikota Manado. Universitas Sam Ratulangi Manado.

Brooks, Geo, F., Busel, Janet, S., Morse, \& Stephen, A. (2005). Mikrobiologi Kedokteran. Jakarta: Salemba medica.

Depkes RI. (2003). Keputusan Menteri Kesehatan RI, Nomor: 942/Mankes/SK VII/2003, tentang persyaratan Hygiene Sanitasi Makanan Jajanan.

Edi. (2012). Bakteriologi online.

Isyana, F. (2010). Studi Tingkat Higiene dan Cemaran Bakteri Salmonella sp pada Pembuatan Dangke Susu Sapi Dikecamatan Cendana Kabupaten Enrekang. Universitas Hasanuddin Makassar.

Jay, J.M. (2005). Modern Food Microbiology. 6th Edition. Maryland: Aspen Publishers.Inc.

Kesehatan Dinas Kota Kendari. (2013). Profil Dinkes Kota Kendari. Kendari.

Narumi, E. (2009). Deteksi Pencemaran Bakteri Salmonella sp. pada Udang Putih (Penaeus Merguiensis) Segar di Pasar Tradisional Kotamadya Surabaya. Fakultas Kedokteran Hewan Universitas Airlangga.

Nindya, Y. permata. (2010). Identifikasi bakteri Salmonella sp pada Makanan Jajanan Dimesjid Fahtullah Ciputat Tahun 2015. Universitas Islam Negeri Syarif Hidayatullah.

Notoatmodjo, S. (2002). Metodologi Penelitian Kesehatan. Jakarta: Rineka Cipta.

Putriana. (2012). Pengaruh Konsentrasi Garam dan Lama Penyimpanan terhadap Kandungan Mikroba Telur Asin. Universitas Hasanuddin Makassar.

Wahab, A. (2011). Uji Cemaran Bakteri dan Identifikasi Escherichia Coli pada Siomay yang Dijual Dibeberapa Tempat Dikota Kendari. Akademi Analis Kesehatan Binahusada Kendari. 